\title{
THE USE OF PROTOZOAN, ROTIFERS AND NEMATODES AS LIVE FOOD FOR SHRIMP RAISED IN BFT SYSTEM
}

\author{
CLÁUDIO KINACH LOUREIRO ${ }^{1-3}$, WILSON WASIELESKY JR ${ }^{2}$, PAULO CÉSAR ABREU ${ }^{3}$ \\ ${ }^{1}$ Programa de Pós-graduação em Aquicultura - Universidade Federal do Rio Grande - FURG - Cx. P. 474 - CEP: $96201-900$ - Rio Grande - \\ RS - Brasil. \\ ${ }^{2}$ Universidade Federal do Rio Grande - Laboratório de Maricultura - Instituto de Oceanografia - FURG \\ ${ }^{3}$ Universidade Federal do Rio Grande - Laboratório de Fitoplâncton e Microorganismos Marinhos - Instituto de Oceanografia - FURG
}

\section{RESUMO}

Utilização de protozoários, rotíferos e nematódeos como alimento vivo para camarões cultivados no sistema BFT O Meio de Cultivo de Protozoários e Nematódeos - PNCM, possibilita a produção de microrganismos de forma barata para a utilização como alimento vivo em cultivos de camarões marinhos. Ciliados produzidos no PNCM foram testados como alimento vivo para pós-larvas de camarões em um experimento com quatro tratamentos: (BFT) somente bioflocos; (BFT 10) $10 \mathrm{~mL}$ de PNCM adicionado ao biofloco; (BFT 100) $100 \mathrm{~mL}$ de PNCM adicionado ao biofloco; BFT 1000) $1000 \mathrm{~mL}$ de PNCM adicionado ao biofloco. Os microrganismos foram analisados nas fases inicial, intermediária e final do experimento, realizado durante 30 dias. A análise do conteúdo estomacal dos camarões indicou a predação dos ciliados pelas pós-larvas. Na maioria dos tratamentos, o período inicial foi marcado pelo incremento dos flagelados, a fase intermediária foi marcada pela redução na abundância de ciliados, a fase final foi representada pelo aumento na abundância de ciliados e rotíferos. Em todos os tratamentos, os nematódeos não foram encontrados nas amostras finais, em nenhuma das três fases de cultivo, sugerindo que estes organismos foram efetivamente predados pelos camarões. Este estudo indicou que ciliados, rotíferos e nematódeos, desempenham importante papel como alimento vivo em larviculturas, principalmente pelo seu tamanho reduzido, valor nutricional e atratividade exercida sobre as pós-larvas.

PALAVRAS CHAVE: biofloco, conteúdo estomacal, microorganismos, larvicultura

\section{ABSTRACT}

The Protozoan and Nematodes Culture Medium - PNCM, enable inexpensively production of microorganism to be used as live food in shrimp culture. It was tested the ciliates produced by PNCM as live food for shrimp larvae in an experiment with four treatments: (BFT) only biofloc medium; (BFT 10) $10 \mathrm{~mL}$ of PNCM culture added to biofloc; (BFT 100) $100 \mathrm{~mL}$ of PNCM culture added to biofloc; and (BFT 1000) $1000 \mathrm{~mL}$ of PNCM culture added to biofloc. The microorganisms were analyzed at the beginning, intermediate and final phases of the experiment which lasted for 30 days. The analysis of shrimp gut contents indicated a predation of shrimps on the ciliates. In most treatments, in the initial period there was significant increase of flagellates, the intermediate phase was marked by the ciliates decrease and the final period was represented by an increase in the abundance of the ciliates and rotifers. Nematodes were absent at the end of the final phase in all treatments, suggesting that these organisms were effectively preyed by shrimps. This study indicate that ciliates, rotifers and nematodes play an important role as live food in hatcheries mainly due to their small size, nutritional value and attractivity exerted on shrimp postlarvae.

KEYWORDS: biofloc, gut content, microorganisms, hatchery

\section{INTRODUCTION}

In the Biofloc-Technology (BFT), with zero waterexchange, macroaggregates or "bioflocs" are formed during the shrimp production cycle with the objectives of reducing wastewater discharge and environmental impact caused by the input of dissolved nutrient.

The microbial flocs are comprised primarily by bacteria, cyanobacteria, algae, protozoans, small metazoans, invertebrates larval forms, feces and dead organisms remains, which could serve as complementary food to shrimps. Some of these microorganisms (heterotrophic bacteria) are able to assimilate the nitrogen compounds from the shrimp excretion and food decomposition, improving water quality (McIntosh et al. 2000, Decamp et al. 2002, Burford et al. 2003, Wasielesky et al. 2006a, Wasielesky et al. 2006b).

The species composition of the natural microbial community, influences the biochemical composition of the floc and therefore, its nutritional value and possibly, palatability to shrimp. Protozoan like flagellates and ciliates contain sterols in their chemical composition, and a large portion of these sterols is converted to cholesterol or other lipid forms. Moreover, dry matter of eukaryotic organisms is composed of $50 \%$ protein, $10 \%$ lipids, $3-4 \%$ of RNA and DNA. Similarly, nematodes biochemical analysis indicated high levels of protein and fat (Biedenbach et al. 1989) but these levels are significantly dependent on the environment where the nematodes are cultured.

Thus, the addition of cultured microorganism in $\mathrm{BFT}$, especially ciliates and nematodes could increase the protein and lipid availability, improving the cultured organisms growth (Phillips 1984; Stolp 1988, Biedenbach et al. 1989, Decamp et al. 2002, Focken 
et al. 2006) and providing a reduction of crude protein used in commercial feed (Samocha et al. 2004).

A technique of massive production of protozoan and nematodes, based on the Martinez-Cordova (2002) method, enabled an inexpensive enrichment of super-intensive shrimp culture with ciliates and nematodes. The method uses alfalfa hay and sugarcane molasses as sources for the growth of microorganisms (Loureiro et al. submitted). The bacteria will act in the decomposition of organic matter using carbon as an energy source, and nitrogen to form the cell structure through protein synthesis. The bacterial growth will allow the establishment of a microbial food web composed by flagellates, ciliates, rotifers and nematodes.

This study aims to determine the use of ciliates, produced by the PNCM, as live food to enrich the BFT system.

\section{MATERIAL AND METHODS}

The study was carried out in the facilities of the Aquaculture Marine Station - EMA of the Federal University of Rio Grande - FURG, at Cassino beach Rio Grande - RS (Brazil). The experiments started on February $1^{\text {st }}, 2010$, and lasted for 30 days.

\section{Protozoan and Nematodes Culture Medium - PNCM}

In order to stimulate the growth of heterotrophic microorganisms, an intensive bacteria, protozoan and nematodes culture was developed for 10 days before the beginning of the trial. Six cylinder-conical tanks were filled with $50 \mathrm{~L}$ of filtered seawater $(5 \mathrm{~m}$ Cuno filter). In each tank, $20 \mathrm{~g} \mathrm{~L}^{-1}$ of sugarcane molasses were added during three consecutive days. Besides, cod liver oil was used at a rate of $18 \mathrm{~mL} \mathrm{~L}^{-1}$ as well as $2 \mathrm{~g} \mathrm{~L}^{-1}$ of yeast (Saccharomyces cerevisiae), $0.2 \mathrm{~g} \mathrm{~L}^{-1}$ of ascorbic acid and $100 \mathrm{~g} \mathrm{~L}^{-1}$ of alfalfa hay (MartinezCordova 2002 modified). The inoculum of microbiota was obtained from $50 \mathrm{~mL}$ of brackish water (20 psu) from Patos Lagoon estuary. All ingredients were mixed up and remained under continuous aeration and temperature around $38^{\circ} \mathrm{C}$.

A 10-mL aliquot was sampled, fixed and stained with Lugol's iodine solution of $2 \% \quad(\mathrm{v}: \mathrm{v})$ for the determination microorganism abundance into the PNCM tanks. Further the identification and quantification of microorganisms, such as flagellates, ciliates, rotifers and nematodes, were done according to Utermöhl method (Throdsen 1978), using an inverted microscope Axiovert 135 ZEISS at $200 \mathrm{X}$ magnification.

\section{Experimental design}

Sixteen 5-L plastic containers with 4 liters of final volume were divided into four treatments as follow: a) with only biofloc (BFT treatment); b) $10 \mathrm{~mL}$ of PNCM culture added to biofloc medium (BFT 10 treatment); C) $100 \mathrm{~mL}$ of PNCM culture added to biofloc medium (BFT 100 treatment) and d) $1000 \mathrm{~mL}$ of PNCM culture added to biofloc medium (BFT 1000 treatment).

The biofloc used in the experiment was originated from a tank production of juvenile Litopenaeus. vannamei at Marine Aquaculture Station EMA. During the study the containers remained in a water-table with controlled temperature $\left(28{ }^{\circ} \mathrm{C}\right)$ and constant aeration. Every container received $50 \mathrm{~L}$. vannamei post-larvae (PL25) $(0.006 \pm 0.003 \mathrm{~g})$ per liter.

The PLs used in this study were obtained at Aquaculture Marine Station hatchery and their survival rate was estimated by counting the PLs at the beginning and the end of study period.

\section{Maintenance of the experimental units}

Water in the tanks was renewed every 48 hours (renewal cycle) by siphoning of almost $90 \%$ of total volume. The original volume was replaced by the addition of water with bioflocs from production tanks located at EMA/FURG. The same amount of preestablished PNCM was added in every container.

\section{Analysis of microorganisms}

The microorganisms were analyzed at the beginning, intermediate and final phases of the experiment. Water samples were collected twice in each phase. For this, after each renewal cycle, $30-\mathrm{mL}$ water samples were taken from containers for quantification of flagellates, ciliates, rotifers and nematodes (initial period sample). Same procedure was repeated 48 hours after water renewal. Differences of microorganism abundance in both sampling periods indicated possible microorganisms consumption by shrimps. Thus initial sample occurred between February $7^{\text {th }}$ (initial period sample) and at February $9^{\text {th }}$, 2010 (final period sample), in the intermediate phase 
sampling was conducted at February $17^{\text {th }}$ (initial period sample) and at February $19^{\text {th }}$, 2010 (final period sample) and the final phase, sampling was conducted at February $27^{\text {th }}$, (initial period sample) and at March $1^{\text {th }}, 2010$ (final period sample).

All samples were preserved in $2 \%$ Lugol's iodine solution ( $\mathrm{v}: \mathrm{v})$ and stored in ambar glass flasks $(50 \mathrm{~mL})$ for posterior analysis of the microorganism community. Aliquots of $2.1 \mathrm{~mL}$ from every sample were analyzed in sedimentation chambers (Throndsen 1978). The quantification was performed using an inverted microscope Axiovert 135 (ZEISS) at 100X, 200X and 400X magnifications (Utermöhl 1958).

\section{Physicochemical parameters}

An YSI ${ }^{\mathrm{TM}}$ mod. 556 sensor was used for daily measurements of water temperature, salinity, $\mathrm{pH}$ and dissolved oxygen. The suspended solids and total ammonia (TAN) concentration were determined at the end of each phase (initial, intermediate and final). For this, Imhoff's cone was used to determine the volume of suspended matter accumulated on the bottom of the cone $15 \mathrm{~min}$ after sampling (Avnimelech 2007). The TAN was determined following the method proposed by UNESCO (1983).

\section{Feed supply}

In all treatments the initial feed supply (Guabi Active $38 \%$ PB) was equivalent to $50 \%$ of the shrimp biomass $\left(0.6 \mathrm{~g} \mathrm{day}^{-1}\right)$. From the fourth day of the experiment period the amount of feed had to be daily adjusted, regarding the surplus of the last time of feeding Shrimp gut content analysis

The analysis was performed on 5 shrimps collected from all treatments on the initial, intermediate and final phases of culture. The dissection was conducted under a stereoscope microscope using dissection needles. The stomach was removed and it's content extruded on a slide, the material was stained with Lugol's iodine solution and identified using an inverted microscope Axiovert 135 (ZEISS) at 100X, 200X and 400X magnifications.

\section{Statistical analysis}

A one-way analysis of variance (ANOVA) was applied to differentiate the survival rate, final weight of shrimps, the dissolved oxygen, the ammonia-TAN concentration and the initial and final abundance of microorganisms. Significant differences at $(p<0.05)$ were determined using the Tukey's test (Zar 1999).

\section{RESULTS}

\section{Zootechnical Indexes}

Survival rates and final weights of the shrimps are presented in Table 1. The shrimps had better survival rates in the BFT 100 and BFT 1000 than in the control (BFT). The final weight of PL in the BFT 10 indicated a higher weight increment than observed in the other treatments.

TABLE 1 - Zootechnical indexes (MD \pm SD) of Litopenaeus vannamei juvenile exposed to: BFT, BFT 10, BFT 100 and BFT 1000 treatments at final of experiment. Different letters indicate sign significant between treatments $(p<0.05)$.

\begin{tabular}{ccccc}
\hline & BFT & BFT 10 & BFT 100 & BFT 1000 \\
\hline Survival (\%) & $44 \pm 2,6^{\mathrm{a}}$ & $42 \pm 3,2^{\mathrm{a}}$ & $53,5 \pm 4,2^{\mathrm{b}}$ & $54 \pm 3,4^{\mathrm{b}}$ \\
\hline Final weight (g) $^{\mathrm{b}}$ & $0,068 \pm 0,003^{\mathrm{a}}$ & $0,085 \pm 0,003^{\mathrm{b}}$ & $0,059 \pm 0,002^{\mathrm{c}}$ & $0,048 \pm 0,002^{\mathrm{d}}$
\end{tabular}

\section{Water Quality Parameters}

As showed in table 2, there were much higher $\mathrm{DO}$ concentrations in the BFT and BFT 10, which were significantly different from the other treatments, as well as there also were higher ammonia - TAN values in those treatments. Apart from this, there were no significant differences among the treatments for temperature, salinity, $\mathrm{pH}$ and suspended matter during all the experiment period (Table 2). 
TABLE 2 - Water quality parameters $(\mathrm{MD} \pm S D$ ) of Litopenaeus vannamei juvenile tanks, exposed to: BFT, BFT 10, BFT 100 and BFT 1000 treatments during the culture. Different letters indicate significant difference between treatments $(p<0.05)$.

\begin{tabular}{ccccc}
\hline & BFT & BFT 10 & BFT 100 & BFT 1000 \\
\hline Dissolved Oxygen $\left(\mathrm{mg} \mathrm{L}^{-1}\right)$ & $7,29 \pm 0,32^{\text {a }}$ & $7,24 \pm 0,41^{\text {a }}$ & $6,35 \pm 0,36^{\text {b }}$ & $4,60 \pm 1,35^{\text {c }}$ \\
\hline Temperature $\left({ }^{\circ} \mathrm{C}\right)$ & $28,02 \pm 0,37$ & $28,12 \pm 0,26$ & $28,02 \pm 0,37$ & $28,12 \pm 0,27$ \\
\hline Total ammonia-TAN $\left(\mathrm{mg} \mathrm{L}^{-1}\right)$ & $0,79 \pm 0,19^{\text {a }}$ & $0,30 \pm 0,14^{\text {b }}$ & nd & nd \\
\hline Salinity $(\% \circ)$ & $32,6 \pm 0,5$ & $32,6 \pm 0,5$ & $32,6 \pm 0,5$ & $32,6 \pm 0,5$ \\
\hline$p H$ & $7,9 \pm 0,18$ & $7,9 \pm 0,22$ & $8,1 \pm 0,17$ & $8,2 \pm 0,14$ \\
\hline Cone Imhoff $\left(\mathrm{ml} \mathrm{L}^{-1}\right)$ & $8,7 \pm 4,2$ & $9,9 \pm 3,8$ & $9,6 \pm 5,8$ & $7,7 \pm 5,5$ \\
\hline
\end{tabular}

\section{Analysis of microorganisms}

The abundances of flagellates, ciliates, rotifers and nematodes in the initial phase (February $7^{\text {th }}$ ) are shown in the Figure 01. In this period of the experiment there was a significant increase of flagellates in most treatments, except in the BFT 100 (Fig. 01B). Overall, there was a decrease in the concentration of larger organisms such as rotifers and nematodes, mainly in the BFT 100 and BFT 1000 treatments, respectively (Fig. $01 \mathrm{~F}$ and $01 \mathrm{H})$.
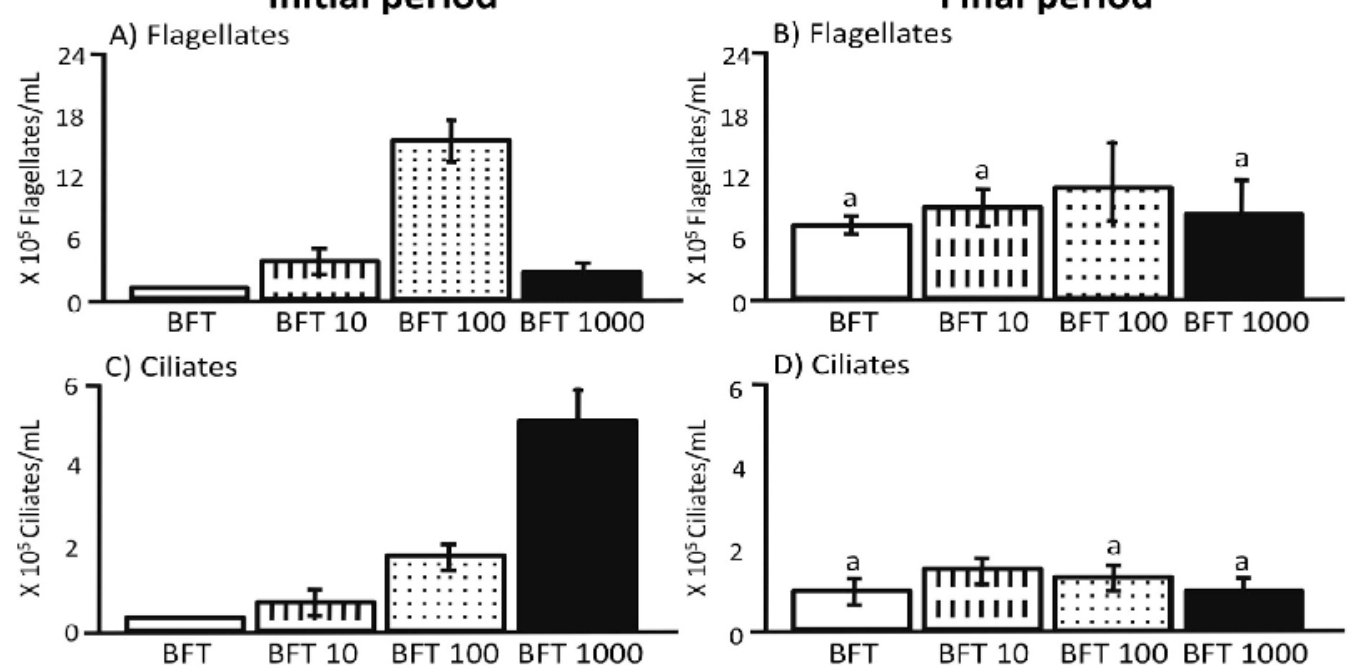

D) Ciliates
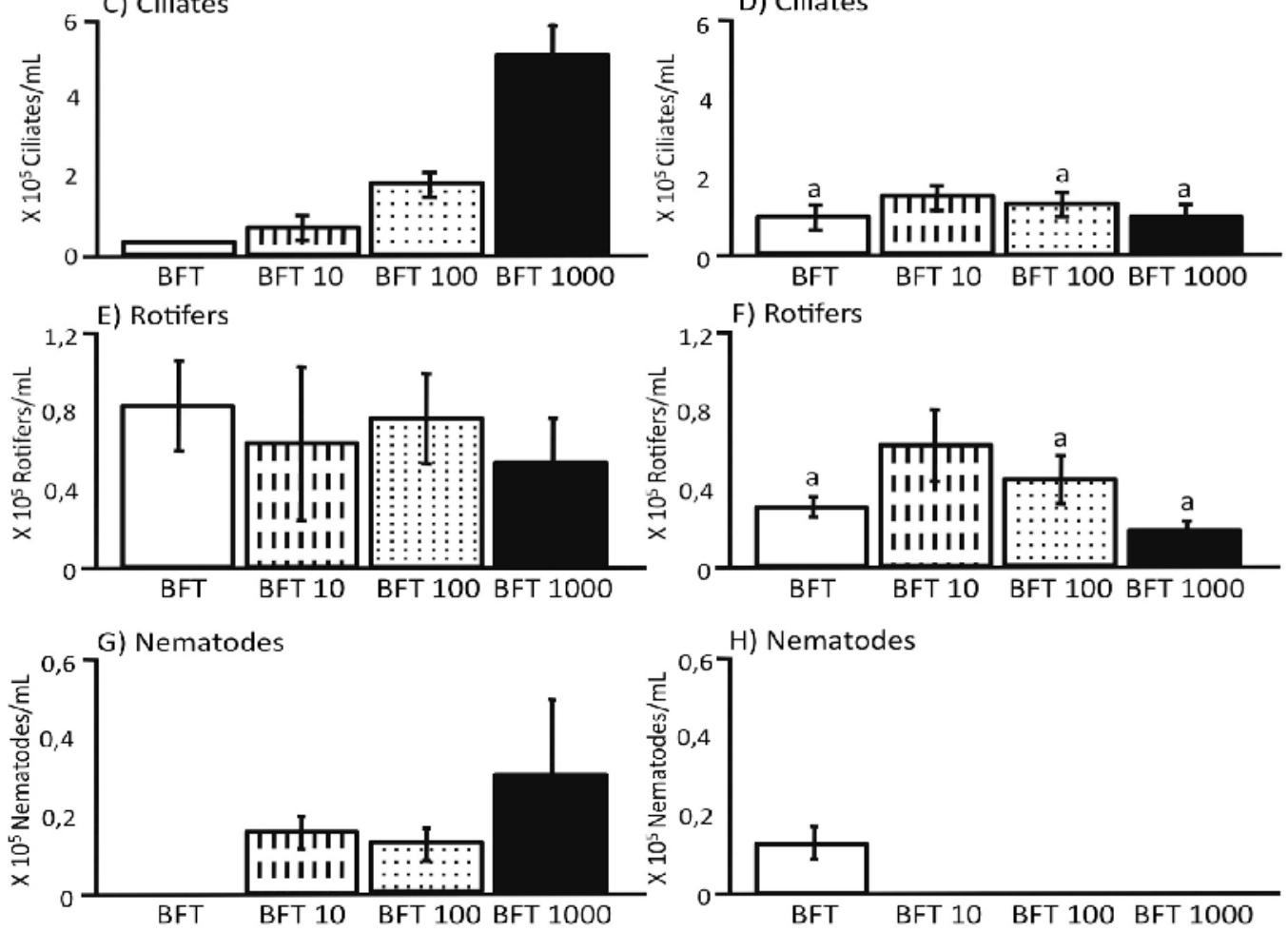

FIGURE 1 - Abundance of A-B) flagellates, C-D) ciliates, E-F) Rotifers and G-H) Nematodes in the beginning and the end of initial phase (7/Feb.). The letter $a$ over the bars (right pictures) indicate significant difference $(p<0,05)$ between the initial and final concentration of microorganisms in every EU (experimental unit). 
A significant increase in the flagellates abundance $48 \mathrm{hrs}$ after the addition of PNCM was also observed in the intermediate phase of the experiment (February $17^{\text {th }}$ ) in BFT 10 and BFT 1000 treatments (Fig. 02B), as well as a significant decrease in the population of ciliates in BFT 100 and BFT 100 treatments (Fig. 02D). Likewise observed for the initial phase, there were a few rotifers left (Fig. 02F) and the nematodes were absent at the end of that intermediate phase (note the lack of the picture for this).
A) Flagellates

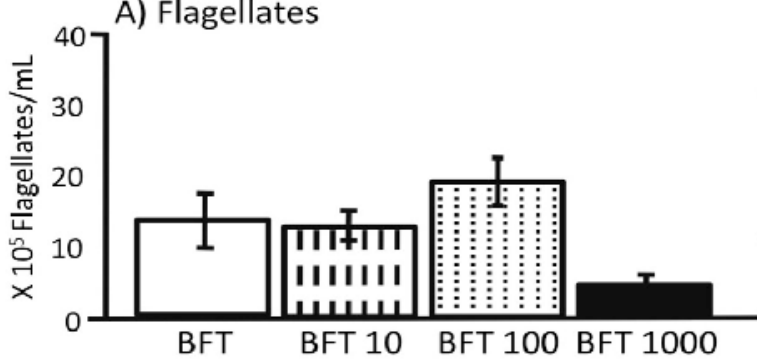

C) Ciliates

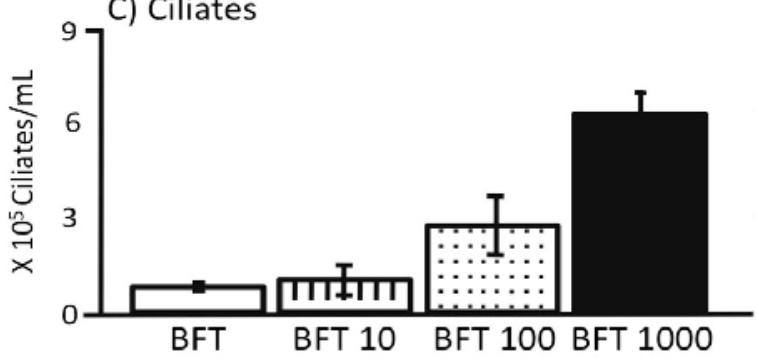

E) Rotifers
B) Flagellates

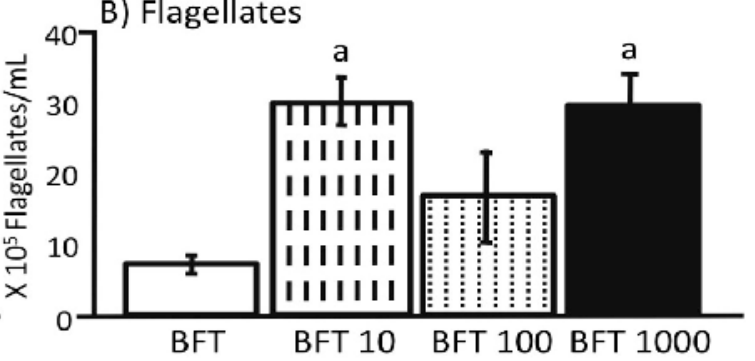

D) Ciliates
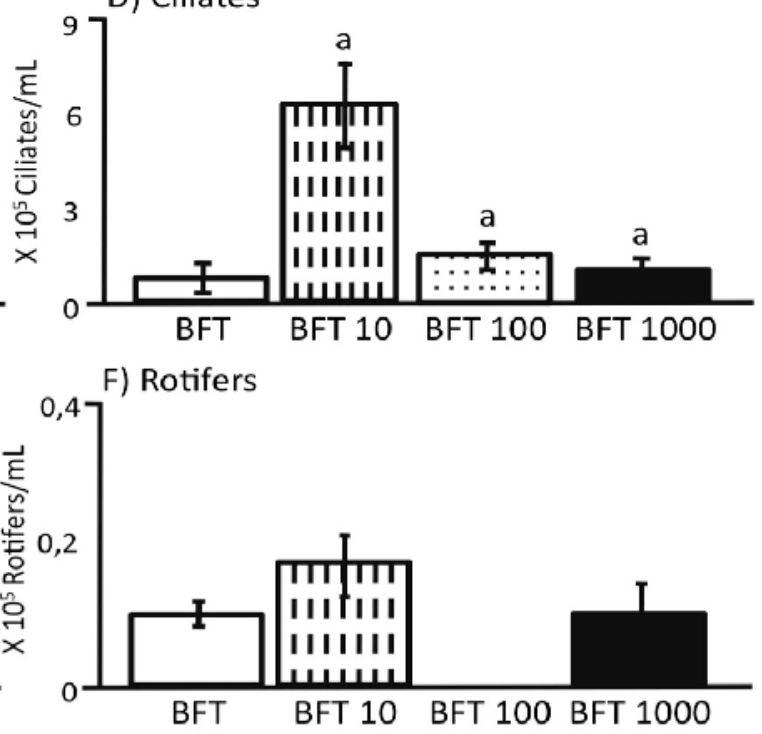

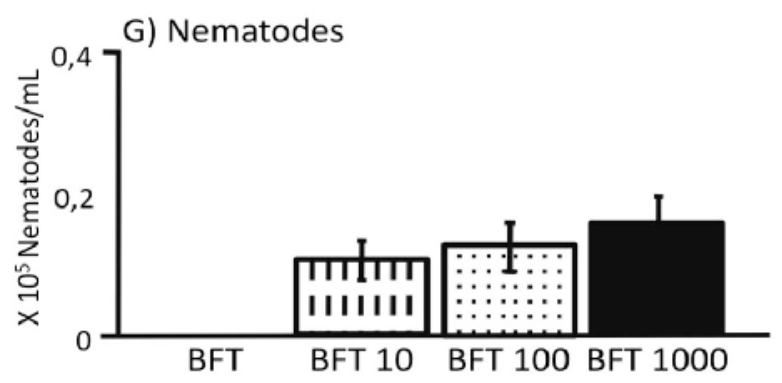

FIGURE 2 - Abundance of A-B) flagellates, C-D) ciliates, E-F) Rotifers and G-H) Nematodes in the beginning and the end of intermediate phase (17 Feb.). The letter a over the bars (right pictures) indicate significant difference $(p<0,05)$ between the initial and final concentration of microorganisms in every EU (experimental unit).

By contrast, the final period (February $27^{\text {th }}$ ) was represented by the increase in the abundance of the ciliates in BFT 10 and BFT 1000, the rotifers abundance increased in most treatments, except in the BFT treatment (Fig. 03F). Despite the presence in the BFT 1000, nematodes were absent at the end of the period of that final phase. There was an increase in the number of flagellates at the end of this final period only in the BFT 10 (Fig. 03B). 

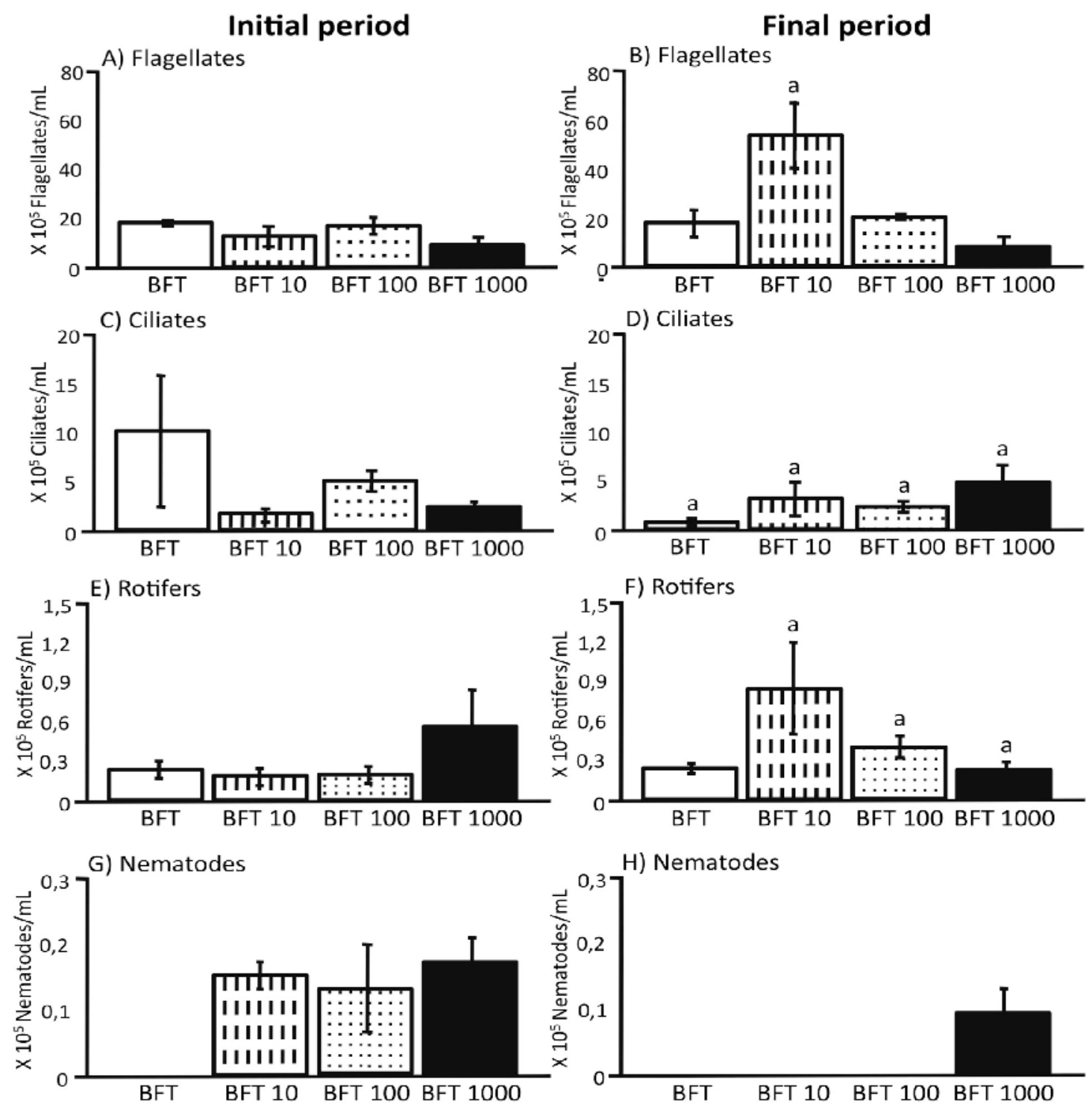

FIGURE 3 - Abundance of A-B) flagellates, C-D) ciliates, E-F) Rotifers and G-H) Nematodes in the beginning and the end of final phase (27 Feb.). The letter $a$ over the bars (right pictures) indicate significant difference $(p<0,05)$ between the initial and final concentration of microorganisms in every EU (experimental unit).

\section{Shrimp gut content analysis}

Ciliates and rotifers were seen in the shrimp gut contents mainly in the initial and intermediate phases of culture, indicating that the shrimp grazed preferentially on these microorganisms especially in the early stages of life. Flagellates and nematodes fragments were not seen at any stage.

\section{DISCUSSION}

The Zooplankton Promoter - ZP was developed by Martinez-Cordova (2002) as a strategy to increase the abundance of zooplanktonic organisms in extensive shrimp culture. The ZP consisted of bunches of alfalfa with sugarcane molasses, vitamins and fish oils, these bunches were bundled and put into plastic net bags, subsequently placed in the ponds at a rate of $4-\mathrm{kg}$ (alfalfa) per hectare. It increased the microorganism growth that benefited the raised shrimp (Martinez-Cordova 2002; MartinezCordova et al. 2002). Some improvements of this technique lead to the development of the PNCM, which promote the development of a microbial food chain, originally represented by flagellates species, ciliates like Uronema sp., Litonotus sp. followed by Euplotes $s p$. and finally by nematodes (Rhabditis sp.) (Loureiro et al. submitted to Aquaculture).

These microorganisms are important source of lipids, proteins and vitamins to aquatic cultured organisms (Abreu et al. 1988; Biedenbach et al. 1989; 
Moriarty 1997; Stoecker \& Capuzzo 1990; Zhukova \& Kharlamenko 1999; Thompson et al. 2001; Decamp et al. 2002; Horowitz \& Horowitz 2002). However, in this work the use of larger volumes of PNCM in the BFT 100 and BFT 1000 treatments, have not reflected in higher growth rates of shrimps. The animals harvested from the BFT 10 and BFT treatments at the end of experiment period presented higher weight, probably due to the lower survival rates of shrimp in these treatments (table 1).

The qualitative and quantitative analysis of populations of heterotrophic microorganism added in the BFT system revealed that ciliates and rotifers have been preyed mainly in intermediate and early stages of cultivation (figs. 1, 2 and 3), this was probably due to the size adjustment of preys and predator, which allowed that microorganisms were directly preyed by the shrimps. These results were confirmed by shrimp gut content analyses, where ciliates and rotifers were only found at the initial and intermediate phase of culture. Others researchers also have confirmed the importance of ciliates (Thompson et al. 2001; Decamp \& Nagano 2004) and rotifers especially in early life stages of cultured organisms, due to the reduced size, as well as the content of protein (Furuya 2001, Ribeiro 2001a). It is interesting to note that in the final phase of the experiment, when shrimps were bigger, ciliates increased in number 48 hours after their addition, indicating that shrimp were ingesting preys of bigger sizes, like nematodes.

The nematode population, on the other hand, was virtually decimated in all phases of the culture, suggesting a possible predation pressure of $\mathrm{PL}$ upon the metazoan organisms, probably due to the larger size of the organisms, which makes them more attractive to predators, also reported by Biedenbach et al. (1989). Biochemical analyses performed on nematodes have showed certain levels of protein, fat and carbohydrates, respectively, $48.3 \%, 17.3 \%$ and $31.3 \%$ in dry weight, but these levels are significantly dependent on the environment where the nematodes are cultured (Biedenbach et al. 1989; Focken et al. 2006), thus those organisms can serve as important nutritional feed items in the Aquaculture.

Although there were no significant differences of microorganisms abundances among treatments, it is likely that the huge numbers of the microorganisms in the BFT 100 and BFT 1000 treatments may have contributed to the lower DO levels, due to supposedly increased microbial respiration rates (Moriarty 1987). Some studies indicate that the dissolved oxygen is the most limiting factor for the growth of penaeid shrimp, and show that decreasing DO levels in the tanks can inhibit their growth and consequently reduce ecdysis (Clark 1986). The oxygen consumption is an important part of the bioenergetic balance of shrimp, because it reflects the energy that is directed to metabolic work. Although it does not act directly on the growth or feed digestibility, it may limit the food consumption and shrimp growth rates (Lucas 1993; Rosas et al. 1998). In contrast, culture environments with low dissolved oxygen levels have been resulted in lower weight of shrimp at the harvest (Rosas et al. 1998; Vinatea 1997; Ribeiro 2001b, Li et al. 2006). However, we believe that the lower final body weight of shrimp in the BFT 100 and BFT 1000 treatments was due to the lack of commercial feed in these treatments where survival rate was higher.

The results of this study indicate that protozoan, nematodes and rotifers produced massively in the Protozoan and Nematodes Culture Medium can be an effective source of live food for cultures shrimp. However, further studies must be conducted in order to improve the survival of shrimp reared at high densities using the PNCM.

\section{REFERENCES}

ALMEIDA, A, D, EM VARANDA \& N PRIMAVESI. 2005. Effect of the inherent variation in the mineral concentration of alfalfa cultivars on aphid populations. Bragantia, 64: 2, 233-239.

ANDREATA, E.R. \& BELTRAME, E. 2004. Cultivo de camarões marinhos. In: Poli, C.R., Poli, A.T.B., Andreatta, R.E., Beltrame, E. (Eds.). Aquicultura: Experiências brasileiras. Multitarefa Editora Ltda, Floranópolis, Chap. 8: 199-220.

ARANA, L.V. 1997. Princípios químicos da qualidade da água em aquicultura. Florianópolis, Editora da UFSC. 165 p.

AVNIMELECH, Y. 1999. Carbon/nitrogen ratio as a control element in aquaculture systems. Aquaculture, 174: 227-235.

AVNIMELECH, Y. 2007. Feeding with microbial flocs by tilapia in minimal discharge bio-flocs technology ponds. Aquaculture, 264: 140-147.

BIEDENBACH, JM, LL SMITH, TK THOMSEN \& A LAWRENCE. 1989. Use of the Nematode Panagrellus redivivus as an Artemia replacement in a larval penaeid diet. Journal World Aquaculture Society, 20: 61-71.

BUFORD, MA, PJ THOMPSON, RH BAUMAN \& DC PEARSON. 
2003. Nutrient and microbial dynamics in high-intensive, zeroexchange shrimp ponds in Belize. Aquaculture, 219: 393-411.

BURFORD, MA, PJ THOMPSON, RP MCINTOSH, RH BAUMAN \& DC PEARSON. 2004. The contribution of flocculated material to shrimp (Litopenaeus vannamei) nutrition in a high-intensity, zero-exchange system. Aquaculture, 232: 525-537.

CLARK, J. 1986. Inhibition of moulting in Penaeus semisulcatus (Haan) by long-term hypoxia. Aquaculture, 52: 253-254.

DECAMP, O., L. CONQUEST, I. FORSTER \& A.G.J TACON. 2002. The nutrition and feeding of marine shrimp within zero-water exchange aquaculture production systems: role of eukaryotic microorganisms. In: Lee, C.S. \& P O‘Bryen (eds.). Microbial Approaches to Aquatic Nutrition within Enviromentally Sound Aquaculture Production Systems. The World Aquaculture Society, Baton Rouge, Chap. 5: 79-86.

DECAMP, O \& N NAGANO. 2004. Ingestion of a ciliated protozoa by first-feeding larval stage of Pacific white shrimp, Litopenaeus vannamei (Boone). Aquaculture Research, 35: 516-518.

FLOODGATE, G. D. 1975. Decomposition processes in the sea with special reference to man-made waste. In: Symposium of the British Ecological Society. Blackwell Scientific Publications, Chap. 17: 223-245.

FOCKEN, U, C SCHLECHTRIEM, A GARC, A PUELLO-CRUZ \& K BECKER. 2006. Panagrellus redivivus mass produced on solid media as live food for Litopenaeus vannamei larvae. Aquaculture Research 1429-1436.

FURUYA, W.M. 2001. Nutrição de peixes. In: Moreira, H.L.M., L Vargas, R.P. Ribeiro \& S. Zimmermann (Eds.). Fundamentos da Moderna Aquicultura. Ed. Ulbra, Canoas, Chap. 8: 59-68.

HARI, B, BK MADHUSOODANA, TV JOHNY, JW SCHRAMA, MCJ VERDEGEM. 2006. The effect of carbohydrate addition on water quality and the nitrogen budget in extensive shrimp culture systems. Aquaculture, 252: 248-263.

LUCAS, A. 1993. Bioénergétique Des Animaux Aquatics. Masson, Paris. $180 \mathrm{p}$.

LI Y, J LI \& Q WANG. 2006. The effects of dissolved oxygen concentration and stocking density on growth and non-specific immunity factors in Chinese shrimp, Fenneropenaeus chinensis. Aquaculture 256: 608-616.

MARTINEZ-CORDOVA, L.R. 2002. Camaronicultura, avances y tendências. México, AGT Editor S.A. 167p.

MARTINEZ-CORDOVA, LR, A CAMPAÑA-TORRES \& MA PORCHAS-CORNEJO. 2002. Promotion and contribution of biota in low water exchange ponds farming blue shrimp Litopenaeus stylirostris (Stimpson). Aquaculture Research, 33: 27-32.

MCINTOSH, BJ, TM SAMOCHA, ER JONES, AL LAWRENCE, DA MCKEE, S HOROWITZ \& A HOROWITZ. 2000. The effect of a bacterial supplement on the high-density culturing of Litopenaeus vannamei with low-protein diet on outdoor tank system and no water exchange. Aquacultural Engeenering, 21: 215-227.

MORIARTY, DJW. 1987. Microbial Ecology in Aquaculture. In: Moriarty, D.J.W., R.S.V. Pullin (eds.). Detritus and Microbial Ecology in Aquaculture. Proceedings of the Conference on Detrital Systems for Aquaculture. Italy, Chap. 1: 1-4.

MOSS, MS. 2002. Dietary importance of microbes and detritus in penaeid shrimp aquaculture. In: Lee, C.S., P O’Bryen (eds). Microbial Approaches to Aquatic Nutrition within Enviromentally

Submetido - 03/05/2011

Aceito $-08 / 02 / 2012$
Sound Aquaculture Production Systems. Baton Rouge, The World Aquaculture Society, Chap 1: 01-18.

PHILLIPS, NW. 1984. Role of different microbes and substrates as potential suppliers of specific, essential nutrients to marine detritivores. Bulletin of Marine Science, 35: 283-298.

RIBEIRO, RP. 2001a. Estrutura das comunidades aquáticas. In: Moreira, H.L.M., L. Vargas, R.P. Ribeiro \& S. Zimmermann (Eds.). Fundamentos da Moderna Aquicultura. Ed. Ulbra, Canoas, Chap. 4: 33-36.

RIBEIRO, R.P. 2001b. Ambiente e Água para a Piscicultura, In: Moreira, H.L.M., L. Vargas, R.P. Ribeiro \& S. Zimmermann (Eds.). Fundamentos da Moderna Aquicultura. Ed. Ulbra, Canoas, Chap. 5: 37-43.

ROSAS, C, E MARTINEZ, G GAXIOLA, R BRITO, R DIAZ-IGLESIA \& L SOTO. 1998. Effect of dissolved oxygen on the energy balance and survival of Penaeus setíferos juveniles. Marine Ecology Progress Series 174: 67-75.

ROSAS, C, G CUZON, G TABOADA, C PASCUAL, G GAXIOLA \& AV WORMHOUDT. 2001. Effect of dietary protein and energy levels on growth, oxygen consumption, haemolymph and digestive gland carbohydrates, nitrogen excretion and osmotic pressure of Litopenaeus vannamei (Boone) and L. setiferus (Linne) juveniles (Crustacea, Decapoda; Penaeidae). Aquaculture Research, 32: 531-548.

SILVA, AA, EM VARANDA \& AC PRIMAVESI. 2005. Effect of inherent variation in the mineral concentration of alfalfa cultivars on aphid populations. Bragantia, 64: 233-239.

STOECKER, DK \& JM CAPUZZO. 1990. Predation on protozoa: its importance to zooplâncton. Journal of Plankton Research, 12: 891-908.

STOLP, H. 1988. Microbial ecology: organisms, habitats, activities. Cambridge University Press. 308p.

THOMPSON, FL, PC ABREU \& R CAVALLI. 1999. The use of microorganisms as food source for Penaeus paulensis larvae. Aquaculture 174: 139-153.

THRONDSEN, J. 1978. Preservation and storage. In: Sournia, A. (Ed.). Phytoplankton Manual. Unesco, Paris Chap. 4: 69-74.

UNESCO. 1983. Chemical methods for use in marine environmental monitoring. Manual and Guides, Intergovernamental Oceanographic Commissiony, Paris. 53p.

UTERMÖHL, H. 1958. Zur vervolkommnurg der quantitativen phytoplankton metthodik. Verhandlungen Internationale Vereinigung fuer Theoretische und Angewandte Limnologie,9: 1-38.

WASIELESKY, W, M EMERENCIANO, E BALLESTER; R SOARES, R CAVALLI \& PC ABREU. 2006a. Flocos Microbianos: um novo caminho a ser percorrido. Revista Panorama da Aquicultura, 96: 14-23.

WASIELESKY, W, HI ATWOOD, A STOKES \& CL BROWDY. 2006b. Effect of natural production in brown water superintensive culture system for white shrimp Litopenaeus vannamei. Aquaculture 258: 396-403.

ZAR, J.H., 1999. Bioestatistical analysis. New Jersey. Prentice-Hall. $660 \mathrm{p}$.

ZHUKOVA, N \& V KHARLAMENKO. 1999. Sources of essential fatty acids in the marine microbial loop. Aquatic Microbial Ecology, 17: 153-157. 